\title{
Conversación en México con Jean Meyer
}

Juan GONZÁLEZ MORFÍN

Universidad Panamericana, México jgonzalezmorfin@yahoo.com.mx

Cortésmente, el Dr. Jean Meyer ${ }^{1}$ aceptó que lo entrevistara para Anuario de Historia de la Iglesia y ofreció recibirme en su casa un viernes de marzo a las cinco de la tarde.

Conforme me aproximo a su domicilio, reparo en el nombre de la calle: Campos Elíseos. Quizá se trate tan solo de una afortunada coincidencia. En otra ocasión le preguntaré si buscó intencionadamente asentar ahí su residencia. En cualquier caso, si bien no compite con Les Champs Elysées, se trata de una avenida arbolada que atraviesa una de las zonas más bellas de la ciudad, cercana al Paseo de la Reforma y al Bosque de Chapultepec.

A las cinco en punto toco el timbre de su puerta y me recibe su esposa invitándome amablemente a pasar, mientras regresa Jean, que ha ido a acompañar hasta el coche a una hija y a uno de sus nietos. Y, efectivamente, antes de dos minutos es el mismo Jean Meyer quien me está invitando a tomar asiento en la sala de su casa.

Comenzamos a hablar de diversos temas relacionados con el objeto de su investigación más conocida: La cristiada, publicada en español en tres volúmenes en $1973^{2}$. Su charla es verdaderamente interesante, pero, para no abusar de su tiempo, le sugiero dar inicio a nuestra entrevista, a lo que él accede complaciente.

1 Historiador e investigador nacido en Niza, en 1942, y naturalizado mexicano (1979). Doctor de Estado en Historia por la Universidad de París-Nanterre (1971). Autor de casi un centenar de libros y de varios cientos de artículos, prólogos y capítulos de libros. Ha impartido diversas cátedras en instituciones de educación superior como la Universidad de Perpiñán, Colegio de México, Colegio de Michoacán, Centro de Investigación y Docencia Económica. Investigador Emérito del Sistema Nacional de Investigadores y Profesor Emérito del Centro de Investigación y Docencia Económica. Actualmente es el director de ISTOR, Revista de Historia Internacional de la que también es fundador. Se pueden obtener más datos sobre su amplia trayectoria en http:// www.cide.edu/perfil/?IdInvestigador $=40$

2 Jean MEYER, La cristiada I-III, Siglo XXI, México, 1973. 
Pregunta. Quizá lo primero que a muchos nos interesaría conocer es sobre sus propios orígenes, pues todos estamos familiarizados con las obras que ha publicado, pero conocemos poco de usted.

Respuesta. Yo nací el 8 de febrero de 1942, en Niza, y eso se debe a la Segunda Guerra Mundial, porque toda mi familia es de Alsacia: mi padre Andrè Meyer, mi madre Anne Marie Barth, son dos apellidos totalmente germánicos y mis dos abuelos, maestros de primaria, pero hijos de campesinos, minifundistas, casi pobres, de familia numerosa... De mi abuelo paterno eran diez hermanos, de mi abuelo materno siete... En ambos casos el cura nota que el muchacho [mi abuelo] es muy inteligente y empuja a los padres a que vaya a la Escuela Normal de maestros de primaria, eso en tiempos de la Alsacia-Lorena alemana, porque mis abuelos nacieron en 1882 y 1884. Mis abuelas también, mismo origen, de familias campesinas, de familias muy católicas, muy practicantes y francófilas a morir. De tal manera que el regreso a Francia, en 1918, para mis abuelos fue una fiesta, y después hubo problemas y tensiones que me contaron...

P. ¿Por qué bubo problemas?

R. Porque en los años 20 hay un gobierno anticlerical en Francia, que pretende cancelar el concordato napoleónico que seguía vigente en Alsacia-Lorena, porque la separación de la Iglesia en Francia es de 1905 y, en aquel momento, Alsacia-Lorena era alemana, por lo que el concordato seguía vigente. Cuando Francia recupera las provincias perdidas, en 1918, hay un compromiso, incluso por escrito, de que respetará los usos y costumbres, incluso el concordato. Y, en 1924 o 1925, el bloque de las izquierdas, con el primer ministro Édouard Herriot, un hombre muy culto, profesor de historia, suspende las relaciones con el Vaticano, brevemente, porque provocó un..., casi un terremoto, y pretendió cancelar el concordato y expulsar a los religiosos, como en 1905, pero, como habían participado en la guerra 1914-1918, todos los veteranos protestaron y hubo una movilización enorme de millones de antiguos combatientes, de veteranos de la Primera Guerra Mundial, y eso pasó...

P. $i Y$ sus padres?

R. En 1940 Francia se derrumba, Hitler la vence y mi padre, que era en esos momentos un joven, un joven maestro de historia en secundaria y prepa, como tal era oficial de reserva, teniente. Le toca la batalla de mayo-junio de 1940, cae preso, herido, dura de junio a noviembre en el campo de oficiales, preso, y en ese momento lo liberan como sujeto del Tercer Reich, porque Hitler anexó Alsacia y Lorena, sin tratado internacional. Cuando mi padre llega a Estrasburgo como liberado, nada más va a saludar a su madre y, al día siguiente, huye al sur de Francia, a la zona que fue libre hasta noviembre de 1942, que no 
ocupaban los alemanes y que administraba el gobierno de Vichy, del mariscal Pétain.

Mi madre, ella había huido. Todavía no estaban casados cuando la guerra. Mi madre era maestra de alemán en Nancy, en Lorena, cuando el 15 de mayo [de 1940] los alemanes pasan a la ofensiva y rompen el frente, los civiles huyen... En tren, pero los trenes son bombardeados... A pie... Finalmente llega a Aviñón, la ciudad de los papas, en Provenza, y ahí se queda. Y, para diciembre, mi padre la alcanza. Se conocían de estudiantes y mi padre preso intercambió muchas cartas con mi madre. Felizmente las conservó; tengo las cartas de mi padre y de mi madre. Y toman inmediatamente la decisión de casarse y se casan en febrero del 41 en Niza, porque a mi padre el gobierno de Vichy lo nombró como profesor en Niza. Mis padres nunca regresaron a Alsacia, porque se encontraba muy bombardeada, imposible de alojarse; se quedaron en Provenza toda la vida.

P. De modo que usted creció y se desarrolló en Provenza...

R. Yo nací en Niza, la ciudad de Garibaldi, la ciudad de Jean-Marie Le Clézio, el premio nobel de literatura, gran amigo nuestro, nos conocimos en México a los veintitantos años y nos hicimos amigos desde hace más de cincuenta años... Yo duré solo unos seis meses en Niza, que era la ciudad donde terminaba el ferrocarril y el día que mi madre no encontró sal, y no encontró cerillos, dijo a mi padre: «No es posible; ¡vámonos!» Y mi padre consiguió un traslado, lo nombraron en Aix-en-Provence y luego mi madre también, a Aix-en-Provence, y ahí fue toda mi infancia y mi adolescencia en la ciudad del gran pintor Cézanne.

P. $i Y$ sus estudios?

R. Estudios normales, clásicos y tuve la suerte, y no es un azar, de tener como maestro de historia y geografía a mi padre en secundaria y en prepa. Mi padre fue a ver al director y le dijo: «Normalmente uno no quiere tener a su hijo en su salón, pero yo no quiero que mi hijo le agarre tirria a la historia». Esto porque la enseñanza de la historia es normalmente mala y por eso los niños aborrecen la historia; y mi padre realmente era un maestro genial, o sea, tenía un don pedagógico... Todavía cuando voy a Francia me encuentro gente ya de ochenta años (yo tengo 73), que se acuerdan de mi padre y dicen: «Ay... las clases de historia del señor Meyer...». Y evocan episodios de cuando mi padre contaba y casi, casi representaba a Bismarck fumando el puro y falsificando la dépêche d'Ems... No falsificando, modificando el famoso telegrama de Ems, que provoca que los franceses pierdan los estribos y declaren la guerra.

P. ¿Abi nace su gusto por la bistoria?

R. Cuando me preguntan: «¿y su vocación de historiador?». Pues yo creo que mi padre me la inculcó sin que yo me diera cuenta, porque cuando entré a la 
Universidad hice un año de propedéutico en Humanidades en general (eso sí, yo no quería ir a Ciencias), y el segundo año, cuando uno escoge la especialidad, yo me encontré sobre el riel de la historia y nunca me bajé.

P. ¿̇Algún interés por seguir los pasos de su padre también como profesor?

R. Otra decisión de mi padre. Quería que yo entrará a la Escuela Normal Superior que es una de esas grandes écoles, fundaciones de la Revolución francesa y de Napoleón, como el Polytechnique. Uno puede discutir si todavía tiene sentido mantenerlas, pero no cabe duda que forman una élite... Entré a la Normal Superior; recibí una excelente formación, tuvimos contacto con los grandes maestros... Tomábamos clases en La Sorbona, lo que me permitió, por ejemplo, tomar clases con nuestro queridísimo Marrou, Henri-Irénée Marrou ${ }^{3}$, gran cristiano, resistente en la Segunda Guerra Mundial, gente que protestaba contra la guerra de Argelia y el uso de la tortura por el ejército francés, el gran especialista francés de san Agustín. Entonces, tomar clases de historia romana con Marrou, o de la Edad Media, o de Bizancio (de Constantinopla), o con el señor Cahen ${ }^{4}$ sobre el islam, creo que hoy en día los estudiantes no tienen esa suerte. Pero, además, en la escuela teníamos seminarios en petit comité, porque en una generación de historiadores éramos veinte. Venía a darnos clase gente como Pierre Vilar ${ }^{5}$, especialista de historia de Cataluña; o el especialista de la Revolución francesa, miembro del partido comunista en aquel entonces (estoy hablando de los años 60s) Albert Soboul ${ }^{6}$, que era un jacobino..., era comunista, pero yo creo que era más jacobino que comunista.

P. ¿Y por la bistoria de México?

R. Terminando esos estudios me dice otra vez mi padre: «No, no, no. Nada de quedarse toda la vida como yo: dando clases en secundaria y prepa (el famoso lycée francés). Tienes que hacer una tesis de doctorado: la universidad...». Yo tenía una formación general. Los historiadores franceses teníamos $60 \%$ de historia, $40 \%$ de geografía, lo que yo creo que es una cosa muy positiva, tanto geografía física, como geografía humana. Y el primer $60 \%$ se dividía en Historia antigua, Edad Media, Moderna... La Moderna termina el 14 de julio de 1789, y la

3 Henri-Irénée Marrou (1904-1977): filósofo de la historia francés. Fue también especialista en la historia antigua del cristianismo y en san Agustín.

4 Claude Cahen (1909-1991): historiador francés de origen judío. Se especializó en el estudio de la sociedad islámica medieval.

5 Pierre Vilar (1906-2003): historiador francés estudioso de la historia de España y, especialmente, de la historiografía catalana.

6 Albert Soboul (1914-1982): historiador francés nacido en Argelia, especialista en la Revolución Francesa y en el periodo napoleónico. Conocido también por sus obras sobre la interpretación de la historia. 
Contemporánea, que empieza el 14 de julio, con la Revolución francesa: francocentrismo, galocentrismo... Pero tres años antes de terminar mis estudios, a mis veinte años había conocido México. Con un compañero tuvimos la posibilidad de viajar a México todo el verano de 1962 (yo acababa de cumplir veinte años): julio, agosto y principios de septiembre. Y me gustó tanto el país que me dije a mí mismo: no sé cómo, pero volveré. A la hora de escoger el tema de tesis en el seminario de doctorado, mi director me propone una tesis sobre Estados Unidos, pues mi tesina de maestría había sido con Piérre Renouvin ${ }^{7}$ sobre el Comité senatorial de 1919 presidido por el senador Nye, es decir, el grupo de senadores del centro de Estados Unidos que decían que su país nunca debió entrar en la Primera Guerra Mundial: los llamados isolacionistas. El senado creó una comisión para demostrar que Estados Unidos había entrado en la guerra para defender los intereses de la industria de armamentos y los bancos, que no querían perder lo que habían prestado a Inglaterra y Francia: para eso, tenían que derrotar a Alemania. Trabajé el informe de 900 páginas. Le contesté al maestro: «yo quisiera trabajar sobre México». Era un hombre muy generoso, Jean-Baptiste Duroselle ${ }^{8}$, que renovó los estudios de la historia de las relaciones internacionales en Francia, católico. Él había hecho su tesis sobre Marc Sangnier et Le Sillon', la democracia social cristiana, es decir, el impacto de la doctrina social de la Iglesia en Francia hasta los años 20-30. Me dice: «yo no soy especialista en México, así que dirigir no voy a poder, pero le doy la cobertura administrativa: le firmo». En ese momento había en París un solo historiador que se interesaba en América Latina, era Pierre $\mathrm{Chaunu}^{10}$, que justo en ese momento estaba abandonando la historia de América Latina publicando una síntesis extraordinaria llamada L'Amerique y Les Ameriques (1964). Era el único que tenía un seminario sobre América Latina. Éramos como quince o veinte, más de la mitad latinoamericanos: había chilenos, argentinos, un mexicano, y los demás éramos franceses, entre ellos un amigo mío que después

7 Pierre Renouvin (1893-1974): historiador francés conocido especialmente por su libro Histoire des relations internationales, publicado en 1954.

8 Jean-Baptiste Duroselle (1917-1994): historiador francés conocido por su incursión en varios temas, principalmente, la historia del catolicismo social y la democracia cristiana en Francia, así como la historia de las relaciones internacionales. Junto con Pierre Renouvin escribió Introduction à l'bistoire des relations internationales (1965).

9 Marc Sangnier (1873-1950): político y periodista francés. Promovió el acercamiento de las clases dirigentes y los obreros sobre todo a través del periódico Le Sillon. Durante la Segunda Guerra Mundial puso sus conocimientos de periodismo al servicio de la resistencia.

10 Pierre Chaunu (1923-2009): latinoamericanista e historiador de la religión francés. Fue también profesor de historia moderna. 
se volvió un experto en historia de Perú, también él, de la Normal Superior. Y yo presento un proyecto sobre Zapata y al profesor Chaunu le parece muy bien... En ese momento, el mexicano levanta la mano, el padre López Moctezuma ${ }^{11}$, jesuita, que en paz descanse: fue un extraordinario maestro en la Iberoamericana; sus alumnos hasta la fecha lo recuerdan con muchísimo cariño. Él había venido a Francia para hacer su tesis doctoral sobre Palafox, el gran enemigo de los jesuitas, nunca la pudo terminar porque daba 25 horas de clase a la semana en la Ibero, pero aportó más como maestro; un gran maestro realmente vale todas las tesis del mundo... Yo le debo el tema de la cristiada, porque él dice: «lo de Zapata es muy interesante, y falta mucho por estudiar, pero ya hay dos que tres muy buenos libros, por ejemplo, Sotelo Inclán: Raíz y razón de Zapata ${ }^{12}$. Si usted busca un tema de tesis realmente novedoso, un blanco en el mapa histórico de México, un tema virgen: la cristiada». Yo no conocía la palabra, el profesor Chaunu tampoco, y entonces nos explica de qué se trata y me entusiasmo con la idea...

P. ¿Utiliza el padre López Moctezuma la palabra «cristiada»?

R. Sí, él utiliza la palabra cristiada... El padre me dio una breve bibliografía: los libros de Jus, del padre Bravo Ugarte ${ }^{13}$, de Mariano Cuevas... ${ }^{14}$ lo poco que había en aquel entonces. El profesor Chaunu comenta: «por lo que dice el padre, el conflicto terminó en 1938, estamos en el 64, la historia es muy reciente: usted va a encontrar los archivos del Estado y de la Iglesia cerrados, usted tendrá que trabajar como Oscar Lewis ${ }^{15}$, ¿usted ha leído Óscar Lewis?» «Pues..., no; ¿quién es?» «Gallimard acaba de publicar su Les enfants de Sánchez, Los hijos de Sánchez. Usted tiene que leerlo para hacer, como él, un trabajo entre antropólogo y periodista, con la grabadora, para entrevistar a los sobrevivientes tanto de los cristeros como del otro lado». Y así fue. En septiembre de 65 llegué a México, gracias al Duroselle generoso... Duroselle había sido maestro de varios mexicanos del Colegio de México, entre ellos, el profesor Rafael Segovia ${ }^{16}$,

11 Jorge López Moctezuma Cumming (1927-2007): historiador mexicano, profesor durante 31 años del Departamento de Historia de la Universidad Iberoamericana.

12 Jesús Sotelo Inclán, Raíz y Razón de Zapata, Editorial Etnos, Anenecuilco, 1943. Existe una versión posterior, publicada por Consejo Nacional para la Cultura y las Artes, México, 1991.

13 José Bravo Ugarte, Historia de México, Editorial Jus, tres tomos, México, 1944.

14 Mariano Cuevas, Historia de la Iglesia en México, cinco tomos, Patria, México, 1947.

15 Óscar Lewis (1914-1970): Antropólogo norteamericano que realizó diferentes trabajos de campo en México y en la India. Se especializó en estudios sobre la pobreza. Su obra más conocida, The Children of Sanchez, Autobiography of a Mexican Family, la publicó en 1961.

16 Rafael Segovia (1928), nació en Madrid y ha vivido en México la mayor parte de su vida desde 1940. Historiador y politólogo, se especializó en Estudios Internacionales. Actualmente es profesor emérito del Colegio de México. 
que lo invitó al Centro de Relaciones Internacionales a dar dos o tres veranos seguidos clases de Historia de Relaciones Internacionales. Duroselle, intuyo, porque es de esa gente generosa que jamás presume de lo que ha hecho, me recomendó con el presidente del Colegio de México, que en ese momento era don Silvio Zavala ${ }^{17}$, que acaba de morir de 105 años, de tal manera que a mis 23 años llego al Colegio como profesor investigador visitante, y me quedé de septiembre de 65 a julio de 69 , dando clase y haciendo mi tesis de la cristiada. Como dijo Chaunu, muchísimo trabajo de entrevistas, viajando por toda la república, lo que fue una experiencia fabulosa.

P. ¿Consiguió que se le abrieran algunos archivos?

R. Archivos oficiales no; pero... el archivo de la Liga, el archivo de Miguel Palomar y Vizcarra, que en ese momento vivía todavía. Después, cuando murió, en su testamento, dejó su archivo personal que había conservado desde sus tiempos de diputado católico y después, de vicepresidente y presidente de la Liga, y como no tenía confianza ni en la Iglesia, ni en el Estado, lo depósito en la UNAM. Y hasta ahora ha tenido razón: se ha conservado bien, está abierto al público.

P. ¿Algún otro archivo?

R. Tuve la suerte de encontrar a un antiguo cristero, don Aurelio Acevedo, que había sido coronel del regimiento Valparaíso, en el norte de Jalisco y sur de Zacatecas, subió a rango de general y fue, al final de la cristiada, 1928 y 29, gobernador civil del estado de Zacatecas. Volvió a participar en los años 30, ya no con las armas en la mano, sino en México, en la clandestinidad, y viajando, incluso fue a Estados Unidos, intentando coordinar, ayudar a los 6,000 o 7,000 cristeros de la llamada Segunda. Don Aurelio había conservado su archivo, su maravilloso archivo de la cristiada del 26 al 29, completo. Archivo militar, archivo civil, con documentación sobre las escuelas de los cristeros, los tribunales, los jueces de paz, la fiscalidad y las finanzas. Tenía también el archivo de la Segunda, correspondencia con ocho o nueve estados en los que hubo focos cristeros en la Segunda. Don Aurelio publicaba cada mes un boletín tamaño media carta, que se llamaba David: una empresa gloriosa, el pequeño David que derrotó a Goliat, el órgano de los veteranos donde don Aurelio publicaba memorias, recuerdos, documentos, fotografías... Él murió agotado, físicamente agotado por una vida muy difícil de trabajo, de pobreza, de grandes riesgos, murió en enero del 69, ni

17 Silvio Zavala (1909-2014): historiador e investigador mexicano. Publicó varios estudios sobre el siglo XVI; el más conocido, La encomienda indiana (1935). Fundador del Centro de Estudios Históricos de El Colegio de México, del que fue director de 1963 a 1966. 
sé si había cumplido 69 años. Tenía una colección fotográfica magnífica, fotos que tomó el fotógrafo de Valparaíso, de los soldados y de la vida religiosa de la época, incluso de la vida cotidiana. Su hijo Cristóbal, después de pensarlo mucho, después de cargar con ese archivo durante muchos años, lo donó a la UNAM y fue a engrosar, o a unirse al archivo de Palomar y Vizcarra, lo que me parece una muy buena decisión, y ahí están los negativos, fotografías de alta calidad que reproduje en La cristiada. Don Aurelio me llevó al Cubilete, a la peregrinación de Cristo Rey, en 1966, yo tenía un año y medio en México, y él me había tomado cariño como hombre mucho mayor. Me llevó el sábado en la tarde a la asamblea de la Guardia Nacional (así se llamaba la organización de los veteranos). El dirigente de la Guardia Nacional era un médico, con rango de general, don José Gutiérrez y Gutiérrez, de los altos de Jalisco, que llegó a ser general en jefe de la División del Sur. Él también tenía un archivo formidable, escribió sus memorias, que volvimos a publicar en una tercera edición, con sus hijos, en 2007. Un hombre de una honestidad absoluta, su testimonio [esas memorias] se puede tomar tal cual. Don Aurelio me presenta a esa gente y les dice: «los va a visitar y, por favor, ténganle toda confianza: es un joven francés, católico, que viene a escribir la historia de la cristiada. Por fin vamos a poder levantar esa loza de silencio, y es la última trinchera de la guerra cristera». Yo recuerdo sus palabras.

P. ¿Fue, entonces, un gran apoyo?

R. Él me ayudó a hacer una encuesta sociológica, que el profesor Rafael Segovia me ayudó a armar, a preparar un cuestionario; después el Colegio de México me ayudó a darle un tratamiento informático. Apenas estaba empezando la informática en ese momento... Me decían: «¿cómo lo vas a hacer?» Les contestaba: «voy a mandar por correo el cuestionario, y adentro un sobre con estampilla para que la gente lo devuelva». «Eso... jolvídate! Sí, sí se hace, claro que se hace, pero el regreso es inferior al 10\%». Aurelio Acevedo anunció, en dos o tres números de David la expedición del cuestionario. Mandé mil y recibí como trescientos y tantos. Sin Aurelio Acevedo eso no hubiera funcionado.

Esa es la historia de La cristiada: cuatro o cinco años de investigación, dos años de redacción y se defiende en París, por pura casualidad, el 12 de diciembre de 1971. Me faltaban dos meses para cumplir 30 años.

P. En su familia que, como usted decía, era una familia muy católica, ¿conocían algo sobre la cristiada?

R. Sabían de la persecución religiosa, mis padres como gente culta habían leído a Graham Greene, El poder y la gloria, pero lo más interesante fue (y es lo que me dio después la idea de realizar un coloquio sobre las naciones extranjeras: el impacto del conflicto religioso fuera de México) que en el verano de 65, 
antes de venir a México fui a despedirme de mis abuelos, que ya eran grandes, e hice bien, porque a tres de los cuatro no los volví a ver, volví a ver solamente a mi abuela materna... Voy a Estrasburgo, y mi abuelo paterno me dice: «vamos al pueblo para que te despidas de las tías y de los tíos, de mis hermanos», o sea, tías abuelas y tíos abuelos, un pueblito que se llama Otterswiller a unos 50 kilómetros de Estrasburgo, pegado a Saverna. Comimos en la casa de una de las tías, estaban todos los hermanos... Esas tías, campesinas, no hablaban el francés, hablaban alsaciano, yo no hablo alsaciano, pero entendía lo suficiente. Esa generación inventó un dicho muy bonito: «alemán no quiero, francés no puedo, alsaciano soy». La gente del pueblo hablaba alsaciano; no podía hablar francés porque no se enseñaba en las escuelas, estaba prohibido, y el alemán no querían. Me dicen: «y entonces ¿a dónde vas? « «oy a México». «¿Méksico? Presidente Calles ${ }^{18}$. Padre Pro...» ${ }^{19}$. Y le pide a su hermana más chica, que tenía 82 años, que fuera a buscar su misal y del misal saca la imagen del padre Pro, y atrás decía la fecha de impresión: 1938. En Alsacia, en la Alsacia profunda en 1964, había viejitas y viejitos que sabían del padre Pro. El hermano mayor de mi abuelo, el tío Franz, Francisco, era de la tercera orden franciscana y de una cofradía de adoración perpetua, se acordaba que, en tiempo del presidente Calles, hubo una gran manifestación en Estrasburgo (él me lo cuenta, no fui a buscar a los archivos franceses), que llenó la plaza mayor, frente a la prefectura, para pedir al gobierno francés romper las relaciones con México, por la persecución religiosa.

P. En alguna ocasión oí un comentario que quizá no tenga que ver con la realidad. Escuché que cuando usted llegó a México tenía la convicción de que el levantamiento de los cristeros había sido promovido por terratenientes que lo que querían era defender sus tierras...

R. Efectivamente, era una hipótesis de trabajo; no digo la única. En París, sobre la cristiada no encontré gran cosa, pero en la biblioteca del Museo del

18 Plutarco Elías Calles (1877-1945): Militar y político mexicano. Presidente de la República entre 1924 y 1928, extendió su influencia en todos los niveles de gobierno durante seis años más, periodo conocido como el Maximato. Durante sus años de presidente, llevó hasta el extremo la legislación que coartaba la libertad religiosa, lo que ocasionó que muchos católicos se levantaran en armas exigiendo que se derogaran esas leyes. La lucha por recuperar la libertad religiosa ocasionó más de doscientos mil muertos y es conocida como guerra cristera o, sobre todo a partir de la obra de Meyer, como la cristiada.

19 Miguel Agustín Pro (1891-1927): sacerdote jesuita fusilado por órdenes del presidente Calles sin seguírsele ningún proceso judicial. Su martirio fue ampliamente conocido en el mundo católico. Fue beatificado en 1988. 
Hombre había muchísimos libros de antropología, tanto mexicanos como norteamericanos, gracias a un antropólogo francés, Guy Stresser-Péan ${ }^{20}$, que había hecho su tesis sobre el «palo volador» de...

-Papantla.

-Se quedó toda la vida en México (su viuda vive todavía en México y ella es especialista en trajes tradicionales mexicanos y publica obras póstumas de su esposo). Este señor juntó una biblioteca formidable: treinta mil libros, empastados. Cada vez que adquiría un libro compraba dos ejemplares, y uno lo mandaba a la biblioteca del Musée de l'homme en París. Gracias a él leí un libro de los años 30 de un sociólogo norteamericano, Paul Taylor ${ }^{21}$, a quien el gobierno norteamericano le había encargado estudios sobre la migración (ya empezaba el problema): una monografía sobre Arandas (Jalisco), en 36-37. Menciona que Arandas había sido un pueblo cristero y que todavía la cosa estaba viva. Ese libro me impactó. Había cantidad de bibliografía sobre la reforma agraria, hacendados, las «guardias blancas»..., algún que otro libro de la izquierda mexicana, denunciando a los cristeros como guardia blanca de los hacendados. Llegando a México caí sobre dos novelas de Guadalupe de Anda ${ }^{22}$, un jalisciense, senador, un líder sindical, diputado, senador por el Partido Nacional Revolucionario, primo o hermano de un de Anda famoso en el cine mexicano de esos años. Esos dos libros, muy bien escritos, restituían de manera maravillosa la lengua de la gente de los Altos. Uno, Los cristeros, es la cristiada; otro, Los bragados, es la Segunda. A los bragados los pinta como unos bandidos, forajidos que después de la cristiada no pudieron regresar a una vida normal: violan a las maestras, cortan las orejas a los maestros de la escuela socialista... Pero en el primero, de la cristiada, que es más ambiguo, pinta a unos jefes cristeros heroicos, entre ellos «el 14» $\gg^{23}$, y otros jefes cristeros sanguinarios, malos, ¡malvadísimos!, que son los que asesinan al 14; la tesis es muy sencilla: gente buena, gente extraordinaria (el señor de Anda conocía muy

20 Guy Stresser-Péan (1913-2009): arqueólogo y antropólogo francés que se especializó en la cultura de los indios huastecos. Se estableció en México en 1962. En el 2008 publicó Viaje a la Huasteca con Guy Stresser-Péan, obra que incluye una selección de fotografías etnográficas realizadas por él.

21 Paul Schuster Taylor (1895-1984): economista norteamericano, especialista en cuestiones agrarias. Publicó en los años 30 una obra de varios volúmenes sobre el trabajo de los inmigrantes mexicanos: Mexican Labor in the United States.

22 José G. de Anda publicó Los Cristeros en 1941 y un año más tarde Los Bragados. Las obras tuvieron poca difusión, quizá por no ser favorables a los cristeros.

23 Con el apodo de «el 14» se conocía a uno de los jefes cristeros más connotados por su acometividad y valentía. Murió en marzo de 1929, en circunstancias no del todo claras, a manos de cristeros que le hicieron diversos cargos y lo condenaron de manera sumaria. 
bien esa gente, porque él era de esa zona, nada más que de la minoría que se fue del lado del gobierno), quiere a esa gente y dice: es inexplicable, esa gente debería de estar con la Revolución, la Revolución defiende a esa gente, han sido manipulados, engañados por el clero. Lo de la gente engañada por el clero no me llamó la atención, pero pensé averiguar lo agrario. Había leído mucho sobre La Vendée, y también sobre el carlismo, antes de llegar a México. Esa mezcla de política y religión, tradición y modernidad. Hay dos escuelas: la escuela hagiográfica, de que los carlistas son santos y de que los vandeanos son santos, y luego la anticlerical, que los ve como fanáticos, bestias pardas. Los marxistas ven detrás de eso lucha de clases. Como no es posible que el pueblo sea contrarrevolucionario, hay que pensar que alguien los manipula; en el caso de La Vendée, los nobles, y en el caso del carlismo, quién sabe quién... Y yo llegué un poco con ese arsenal que en seguida no funcionó.

P. ¿Y encontró algunas similitudes?

R. En el caso de La Vendée, sí: queda la religión y un ejército de campesinos que no puede salir a derrotar al gobierno, y otra cosa que me llamó la atención es que, una vez derrotada La Vendée, quedan, irreconciliables e invencibles los Chuanes, una pequeña guerrilla que dura años. Y aquí, usted tiene la gran guerra de la cristiada, que es como la gran guerra de La Vendée, y después tiene «la Segunda», que por cierto, la palabra es muy bonita porque yo pregunté la primera vez: «¿la Segunda? ¿Y la Segunda qué?...» «No, no, la Segunda». Y yo insisto, inocentemente, y se me molesta el señor y me dice: «¿Pero usted no entiende?» «Perdón..., no. ¿Es la segunda cristiada?» «Justamente no podemos decir cristiada; por eso es la Segunda, porque el papa había prohibido levantarse en armas. A partir de 1932 el papa y los obispos ¡nos prohibieron levantarnos en armas! Y nosotros teníamos que levantarnos en armas. Entonces no podíamos decir cristeros, no podíamos decir ¡viva Cristo Rey!». Por eso solo fue la Segunda...; las palabras cuentan, ¿eh?

P. ¿Y todo esto le bizo cambiar su bipótesis de trabajo?

R. Sí, entonces contesto a su pregunta: en aquel momento la formación que recibimos nosotros era economía y sociedad, no forzosamente marxista, pero sí con la idea de que las estructuras de propiedad, las relaciones económicas, son decisivas. Había que examinar la cuestión de la tierra, pero rápidamente esa hipótesis desapareció por una razón muy sencilla: la reforma agraria viene después de la cristiada. Había ya algo de reparto agrario, pero siempre muy limitado en el tiempo: para recompensar gente fiel después de un cuartelazo, o después, por ejemplo, de la rebelión delahuertista, e incluso, en 1929, antes de los arreglos de junio, el presidente Portes Gil empieza a repartir tierras para desarmar el movi- 
miento y termina la cristiada y se acaba. La reforma agraria comienza en 1932, antes de Cárdenas, ahora la versión oficial es que fue con Cárdenas, ciertamente, él la hizo, pero empezó en 32, después de la cristiada.

P. Otra pregunta sobre los orígenes de la guerra cristera, de la cristiada: ¿En un libro publicado por el P. Nicolás Valdés, donde no sé si con su permiso, o sin él, publica todas las cartas que supuestamente intercambiaron...

R. Mire, el P. Nicolás Valdés ${ }^{24}$ ya había muerto, y fue Luis Sandoval quien lo publicó. Él lo publicó sin consultarme, y me lo mandó pidiéndome disculpa. La verdad..., bueno, hay dos que tres cartas que yo no hubiera publicado, pero yo las escribí, no tengo por qué arrepentirme...

P. Hay una, concretamente, en la que usted da noticia de que ya consiguió más documentación sobre la persecución de la época pre constitucionalista, 1915-1916, la persecución de Carranza: ¿en algún momento su tirada era abarcar en su tesis la persecución desde esa época?

R. Vamos..., la trato brevemente en los antecedentes de la crisis, en uno de los tres tomos de La Cristiada, que publicó Siglo XXI y que siguen publicando hasta la fecha, brevemente trato de esto. Lo que pasa es que en Guadalajara, un viejo amigo, don José Ramírez Flores, viejo amigo que murió en 1983, de por lo menos 83 años, había sido maestro de don Luis González y González y del señor Alejandro de Alba que creó el Colegio de Jalisco, y don José tenía una curiosidad universal, lo mismo de arqueología que de botánica, un espíritu enciclopedista, pero la historia era su fuerte, el coleccionaba folletos y lo que no podía comprar lo fotocopiaba. Tenía una serie de documentos fotocopiados sobre el famoso $\mathrm{Pa}$ redes, no sé si hasta ahora alguien lo ha estudiado, pero ahora que los archivos romanos están abiertos se podría hacer, el canónigo Paredes...

-Antonio de Jesús Paredes ${ }^{25}$, ;interesantísimo!

-A eso aludía yo..., pues como no conozco el tema más allá de aquello que se decía en la época y algunos lo acusaban de haberse vendido al carrancismo y otros decían: de manera oportunista, pero realista, está defendiendo la Iglesia. Yo creo

24 Nicolás Valdés (1907-1982) fue un sacerdote e investigador jalisciense que por iniciativa propia consiguió grabar cerca de 800 horas de entrevistas con quienes habían participado en la guerra cristera. Actualmente esas cintas se encuentran depositadas en el Archivo de la Arquidiócesis de Guadalajara y en el Centro Regional del Instituto Nacional de Antropología e Historia de Guadalajara.

25 Antonio de Jesús Paredes (1860-1920): Nació en la capital del país. Estudió en el Colegio Pío Latinoamericano. En ausencia del arzobispo de México, gobernó la arquidiócesis como vicario general entre 1914 y 1919. Mantuvo una gran cercanía con los gobiernos liberales y revolucionarios. 
que debe haber sido algo así. Posiblemente simpatizaba con la Revolución. Ahora bien, lo que sí sabemos es que Carranza personalmente no era anticlerical, y que incluso él intentó, cuando el Constituyente de Querétaro, frenar, si no podía impedir, por lo menos bajar el tono de los artículos anticlericales. Y, en cuanto pudo, puso fin a esa guerrilla, invitó a los obispos a regresar, y antes de que muera él, los obispos pueden regresar, preparó una revisión de la Constitución, pero se le levantan Obregón y todos los sonorenses y lo matan en Tlaxcalaltongo. Así que...

P. ¿Le interesaba solo por ser antecedente?...

R. Sí, me interesaba solo por ser antecedente.

P. ¿No quería bacer algo de una tirada tan larga sino solamente concentrarse en?...

R. No, yo quería concentrarme sobre la cristiada y, fíjese, mi tesis, los tres tomos de La cristiada de Siglo XXI han de ser como novecientas páginas y corté como la tercera parte; la tesis de doctorado en mimeografiado son como dos mil cuartillas. Lo esencial está en el libro, pero había muchos documentos, muchos de Aurelio Acevedo, muy ricos, que tuve que quitar, y eso que Siglo XXI aceptó mucho material, pero, volviendo a su pregunta, el personaje de Paredes es el que realmente me llamó la atención y creo valdría la pena...

-Tengo un artículo en Anuario de historia de la Iglesia... ${ }^{26}$

-Interesante...

-Se lo puedo enviar por lo que pudiera contener que usted no conozca. A míme tocó trabajarlo en los archivos vaticanos y había una preocupación seria en la Santa Sede sobre este personaje...

-Claro, temían una «iglesia nacional»... algo por el estilo, ¿no?

- Marta Eugenia García Ugarte, en un artículo en el que trata algo sobre él, piensa que bubiera sido el obispo ideal para esa época, y yo comparto parcialmente... ${ }^{27}$.

-Sí, sí...

-Por su gran capacidad de negociación para una época como esa.

-Quizá sí salvó lo que se podía salvar.

P. Y, regresando al tema de la cristiada, ¿la ba dejado ya? ¿Sigue investigando? ¿Podemos esperar nuevos libros de usted sobre la cristiada?

R. No, no, nuevos libros no. Realmente, si usted ve, hay una cola larga de libros. Las dos vetas paralelas que he trabajado son: el mundo fuera de México,

26 Cfr. Juan GonZÁlez Morfín, Antonio de 7. Paredes y el régimen carrancista: entre el colaboracionismo y el cisma, en Anuario de Historia de la Iglesia, 24 (2015), pp. 359-381.

27 Marta Eugenia GaRCÍA UGARTE, Debilidades y fortalezas de los obispos mexicanos durante la Revolución (1910-1914), en Libro Anual de la Sociedad Mexicana de Historia Eclesiástica IV (2010). La Iglesia en la Revolución Mexicana, Minos III Milenio, México, 2011, pp. 14-52. 
por ejemplo, el libro colectivo que se llama Las naciones frente al conflicto religioso en México ${ }^{28}$, donde está Chile, América Latina, Europa...

-Hay algunos artículos muy interesantes, como el de Massimo de Giuseppe...

-Parece que ha despertado vocaciones. Luego, un libro de Estados Unidos: La cruzada por México ${ }^{29}$, sobre los católicos americanos. Para mí fue un descubrimiento ese apoyo muy fuerte de los católicos norteamericanos, no solamente de los Caballeros de Colón (Knights of Colombus), sino también de los católicos en general y de los obispos, como...

-Hacer justicia a los Estados Unidos.

-Claro que hacerles justicia, en contra de esas versiones casi xenófobas... Por ejemplo, en los años 30, no recuerdo la fecha exacta, pero en tiempo de Cárdenas, mandan una comisión tripartita: un católico, un protestante y un judío. ¡Mis respetos! Es ecumenismo y no solamente ecumenismo cristiano, más allá: judeo-cristiano. Y los tres mandan un informe devastador, que transmiten al presidente Roosevelt para decir: es cierto, en México hay persecución religiosa. Recuerdo que en 1928 el gran rabino de Berlín también manifiesta su preocupación por los católicos mexicanos, e invita a sus fieles a rezar por los creyentes perseguidos en México. Son cositas, pero son perlas muy bonitas. Faltaría el tercer tema, la oposición a la lucha armada entre los católicos. Es el tema de los estados en los que no hubo lucha armada, en los que hubo arreglos (ahí está mi libro sobre Oaxaca) ${ }^{30}$. Pasó lo mismo en Chihuahua y pasó lo mismo en varios estados del norte. En Yucatán, donde no llegó la persecución religiosa. Hubo gobernadores que hicieron como que aplicaban la ley y la única diferencia es que el obispo estaba en el extranjero, pero el administrador era el deán del cabildo, o el vicario general, el seminario seguía funcionando, no había culto público, pero había culto privado y, a diferencia de la ciudad de México, y de otros muchos estados, la policía no iba a molestar a la gente. Era un arreglo como en Oaxaca: si hay levantamiento cristero yo [gobernador] no puedo hacer nada porque interviene la federación, entonces ustedes, obispos y sacerdotes, contrólenme a su gente (y fue el caso del obispo de Chihuahua, que prohibió el levantamiento en el 27, y le hicieron caso). Finalmente faltaría estudiar los que o por razones de realismo, o por razones éticas, estaban en contra de la lucha armada, que sería

28 Jean MEYER, Las naciones frente al conflicto religioso en México, Tusquets, México, 2010.

29 ID., La cruzada por México, Los católicos de Estados Unidos y la cuestión religiosa en México, Tusquets, México, 2008.

30 ID., El conflicto religioso en Oaxaca (1926-1938), CIESAS - UABJO - Instituto de Artes Gráficas de Oaxaca, Oaxaca, 2006. 
el caso de Mons. Orozco y también el caso de Anacleto González Flores, con la diferencia de que, una vez que empezó la lucha armada, entonces ni modo... Pero me consta que Mons. Orozco le había ordenado a Anacleto impedir que la Unión Popular se fuese al levantamiento. Y Mons. Orozco, al que pintan como integrista, como un caballero templario, un cruzado, aceptaba que los crucifijos se quitaran de las escuelas católicas, para que pudiesen seguir abiertas. Él estuvo en contra de la suspensión de los cultos. Y cuando se tomó la decisión, se regresó corriendo a Guadalajara para intentar aplacar el pueblo, porque pensó: la gente se va a levantar... Él conocía a su gente. Entonces, sí falta matizar muchas cosas...

P. ¿Y no ha habido algún cambio en su..., llamémosle preferencias de investigación? ¿No es que haya cerrado ya la página de la cristiada?

R. Mire, lo que pasa es que... tengo 73 años, y la vida es breve y quiero terminar algunas cosas. Esos libros, esos últimos libros que he hecho, casi siempre han sido accidentales. El de Oaxaca, porque en el 2004, cuando nos tocó un año sabático, a mi esposa y mí (no estamos en la misma institución, pero los dos historiadores y felizmente tenemos el mismo calendario) nos invitaron a Oaxaca seis meses, y aprovechamos los seis meses para trabajar en los archivos locales. El obispo me abrió el archivo, que estaba totalmente catalogado, y el archivo del estado estaba abierto, pude verlo, pero estaba en una situación bastante lamentable, bastante triste... Tuve el material suficiente para sentirme en la obligación de escribir un libro, porque el material era fabuloso. Por ejemplo, cuando el gobernador, manda decir al director del seminario: «oigan, mis enemigos han logrado que el lunes vengan unos inspectores de Gobernación. Supuestamente el seminario está cerrado y con sellos, así que, por favor, desaparezcan». ¡Es extraordinario! Y, luego, cartas de un oaxaqueño que vivía en México pero que es de la Liga, que escribe a un amigo de Oaxaca enojadísimo acusándolo y acusando el clero de Oaxaca y al obispo de Oaxaca de ser «nicodemistas»: «Nosotros estamos luchando y ustedes en santa paz, y viviendo tranquilos, qué vergüenza». Sentí la obligación de escribir el libro...

En 2014 tuve que meterme, no publiqué nada sobre eso, pero tuve que meterme en la diócesis de Jalapa, en Veracruz, para el aniversario de la erección de la diócesis, quizá el centenario. Me invitaron a dar una conferencia, me invitaron con un año de anticipación, y querían que yo hablara del conflicto religioso en Veracruz, especialmente de Mons. Rafael Guízar ${ }^{31}$, que conocía un poco... No

31 Rafael Guízar y Valencia (1878-1938): obispo de Veracruz desde 1919 hasta su muerte. Durante las persecuciones religiosas, siempre evitó las confrontaciones optando por esconderse y sufrir 
publiqué, pero sí es un tema fascinante, un obispo que está en contra de la lucha armada, respeta y admira a los cristeros, él viene de Cotija y de una zona totalmente cristera, el general Degollado Guízar es su primo hermano, pero él piensa, como Anacleto, que como los primeros cristianos hay que morir de rodillas en el circo bajo el diente de los leones, palabras de Anacleto, y él organiza (es otra variante) una Iglesia clandestina...

P. ¿De esto piensa escribir?...

R. No, porque me caen compromisos constantemente. Por ejemplo, ahora es mí último año, mi tercer año de la comisión evaluadora del $\mathrm{SNI}^{32}$ : me toma casi tres días por semana. La sesión plenaria del lunes, luego ver los expedientes en línea, que esto casi no es nada, eso en unas horas se hace, pero son insuficientes, y a veces engañosos y hay que ver el material mismo en las cajas, en el CONACYT ${ }^{33}$. Además quiero terminar o proseguir el tema del antisemitismo cristiano para llegar hasta la..., eso lo estoy soñando, no sé si lo alcance a escribir, la reconciliación: a la hora del Concilio [Vaticano II], pero desde antes del Concilio. Porque tengo material de familia: mis padres, en Aix-en-Provence, a través del médico de familia, una santa mujer que debería tener su nombre entre los justos en Jerusalén, porque durante la guerra organizó una red que salvó a muchos niños judíos, una mujer médico, de las primeras mujeres médico de Francia, nuestra médica, la partera de mi hermana, conoció todavía a mi esposa y a mis primeros niños, pero ella murió en el 78, trabajando, se cayó corriendo en una escalera y ahí murió, y esa mujer atendía a un señor Jules Isaac, ${ }^{34}$ ¿no sé si conozca usted la colección de libros de historia (porque en México también se publicó) que se llamaba Malet et Isaac, traducidos en los años 40-50 en México por las escuelas privadas católicas...

- No.

los atropellos. Se opuso a la suspensión de cultos ordenada por el episcopado en 1926: «iMéxico necesita el pan de su religión!», sostenía. Famoso por sus visitas pastorales en forma de misión. Fue canonizado por Juan Pablo II en 1995.

32 Sistema Nacional de Investigadores, otorga el nombramiento de investigador nacional a aquellos que, evaluados por pares, demuestran haber publicado trabajos con mérito científico. Esto les permite acceder a estímulos económicos.

33 Consejo Nacional de Ciencia y Tecnología, un organismo público descentralizado que coadyuva con la administración pública en la elaboración de las políticas de ciencia y tecnología en México. Una de sus funciones es ejercer el control del Sistema Nacional de Investigadores, por lo que almacena los documentos publicados por estos.

34 Jules Isaac (1877-1963): historiador y editor francés. Dedicó parte de su vida a investigar las causas del antisemitismo y a buscar removerlas. 
-Bueno..., este señor Jules Isaac fue un gran historiador, de la generación de Marc Bloch ${ }^{35}$, hizo la Primera Guerra Mundial, como Marc Bloch, y pertenecía a una vieja familia judía de militares agnósticos desde la Revolución francesa: el bisabuelo, judío, entra a los ejércitos de la Revolución, termina como general de Napoleón, su hijo oficial, su nieto oficial y el señor Jules Isaac es el primero de la familia no militar, es historiador, esto para decir que de judío no sabe nada. Llega la Segunda Guerra Mundial y los nazis arrestan a su esposa y a su hija, que mueren en campos de concentración. Él, de pura «chiripa», había bajado a la ciudad -era un sábado- al mercado. Cuando regresa los vecinos le dicen: «no entre, no entre a su casa, vino la Gestapo y se llevó a su esposa». En aquel entonces -era 1942- no se sabía de la «solución» final. Él quiere ir a la Gestapo para saber qué ha pasado, o eventualmente entregarse, y los vecinos le dicen que no, que no... Va, y las cosas de la burocracia, cuando llega, está cerrada la oficina y el soldado le dice que regrese el lunes. Y logran convencerlo de esconderse. Es cuando el señor descubre qué significa ser judío; su esposa y su hija no regresaron... Tiene otros dos hijos que no murieron porque eran oficiales, prisioneros de guerra, uno se hizo protestante, el otro, católico. Jules Isaac, como historiador, que descubre que es judío y que por eso matan a su esposa y a su hija, investiga de dónde viene ese odio. Escribió una serie de libros muy importantes: uno se llama fesús e Israel donde de manera, yo diría, casi profética, está diciendo lo que hoy en día dicen los mejores especialistas cristianos, que Jesús es un judío de su tiempo. Y luego tiene otro libro que se llama La enseñanza del desprecio: raíces cristianas del antisemitismo, sobre libros de texto, catecismos y toda esta literatura del «pueblo deicida». Se plantea: pero si ya desde el Concilio de Trento se dice que no es cierto, ¿cómo es que el concilio no pudo convencer a esa gente? Y, si san Bernardo dice «no toques a Israel porque es la niña del ojo de Dios...». Como era un hombre muy conocido, a través de la diplomacia francesa consigue una entrevista con Pío XII, en 1949, para que se quite de las oraciones del Viernes Santo, de los famosos improperios, el pro perfidis judeis, y Pío XII accede. En ese momento él ha fundado una asociación que se llama «Amistades judeo-cristianas». Mis padres, muy jóvenes, se habían hecho amigos de Jules Isaac, de modo que él los mete en «Amistad judeo-cristiana». Yo era chico, pero en la ciudad de Aix, me di cuenta que era muy importante. Existía en aquel entonces «la parroquia universitaria»; la mitad de los profesores de la universidad eran católicos practicantes, grandes historiadores, como Georges

35 Marc Bloch (1886-1944): historiador francés, iniciador de la Escuela de los Annales y especialista en la historia de la Francia medieval. Murió fusilado a manos de los alemanes junto con otros miembros de la resistencia francesa. 
Duby $^{36}$, especialista de la edad media, o el decano Rémy Palanque ${ }^{37}$, especialista de la antigüedad cristiana, del tiempo de Roma, del bajo imperio... Toda esa gente estaba en la amistad judéo-chrétienne y no solamente hubo una red en toda Francia, sino fuera de Francia. Incluso en México, con Mons. Carlos Aguiar ${ }^{38}$ y el rabino Marcelo Rittner ${ }^{39}$, fundamos algo más o menos equivalente, la Confraternidad judeo cristiana. Jules Isaac tuvo una entrevista con Juan XXIII, y Juan XXIII dijo: «no solamente se quitan esas palabras, sino muchas cosas más...» (levantó acta después de la entrevista, dio copias a mis padres...). Entregó un memorándum a Juan XXIII, Juan XXIII convoca al cardenal Bea para fundar la subcomisión que va a elaborar Nostra aetate que es realmente el principio de la reconciliación. El viejo Isaac era sordo y, cuando lo presentan al papa, no sabía cómo tenía que saludar al papa, y el papa llegó muy afable y Jules Isaac le dijo: «perdone a un anciano sordo» y el papa le dijo: «no se preocupe, anciano yo también; ¿cuál es su oído bueno?...», «Este». Lo agarró de la mano y lo sentó a su lado y, cuando terminó Jules Isaac, el papa le dijo: «mucha gente cree que la Iglesia es una monarquía absoluta, pero no, es una democracia... Y hay muchas corrientes; así que yo no puedo imponer algo». Entonces es cuando convoca al cardenal Bea y Jules Isaac le dice, ya de pie, «¿puedo esperar algo», y el papa: «desde luego, puede esperar mucho». Los dos murieron antes de que culminara eso.

De ahí nace mi libro La fábula del crimen ritual. El antisemitismo en Europa 1880-191440, cuyo hilo conductor son los artículos antisemitas de La Civiltà Cattolica, y aprovecho para pintar todo el antisemitismo europeo de la época, que es mucho más que católico, que es mucho más que protestante y ortodoxo, es también materialista, es también de izquierda... También me gustaría escribir el libro contrario, el libro de los cristianos que nunca cayeron en esa trampa o en ese error. He acumulado muchísimos documentos sobre la historia de la Iglesia de Rusia, que también fue una Iglesia perseguida, que tiene un récord de mártires.

36 Georges Duby (1919-1996): historiador vinculado a la escuela de Marc Bloch. Se especializó en el estudio de la Edad Media.

37 Jean-Rémy Palanque (1898-1988): historiador francés especializado en historia antigua y religiosa.

38 Carlos Aguiar Retes nació en 1950, fue nombrado obispo en 1997 y desde el año 2009 es arzobispo de Tlalnepantla, una de las diócesis más pobladas de México. Fue presidente de la Conferencia Episcopal Mexicana (2006-2012) y también del Consejo Episcopal Latinoamericano (20112015).

39 Marcelo Rittner rabino judío nacido en Argentina y conocido por sus libros y programas de autoayuda. Vivió algunos años en Brasil y desde 1985 es el rabino principal de la Comunidad Bet-El de México.

40 Jean MEYER, La fábula del crimen ritual. El antisemitismo en Europa 1880-1914, Tusquets, México, 2012. 
Eran más de 120 millones de habitantes, pero tiene más de 50,000 mártires entre sacerdotes, monjes, monjas, diáconos, doscientos obispos..., entre 1919 y 1939. He escrito un libro que se llama La gran controversia ${ }^{41}$, sobre por qué no logran reconciliarse ortodoxos y católicos, pero me gustaría escribir ese libro sobre la historia de la Iglesia en Rusia y el de los cristianos que no cayeron en el antisemitismo. Finalmente, para hacerle el cuento breve, si usted hubiera llegado un poco antes, aquí había dos niños: una niña de seis meses y un niño de siete meses, que son nuestros quinto y sexto nietos, tenemos la suerte de que esos viven aquí, y estamos ayudando a los jóvenes papás, que trabajan, que no quieren dejar el niño en una guardería. Dos mañanas y una tarde por semana nos tocan a mi esposa y a mí esos niños, y creo que también es muy importante... ¿No?

P. Pasando a otro tema, para algunos que aún no ban leído La cristiada, usted es bastante conocido como columnista. ¿Cuándo empezó esa labor?

R. Uf, hace muchísimos años, en Zamora Michoacán. Cuando Luis González funda el Colegio de Michoacán ${ }^{42}$ nos invita. Beatriz y yo somos de los fundadores, de «los doce apóstoles» del Colegio de Michoacán y, en Zamora, había...

-El semanario Guía.

-Guía. Guía me ofreció escribir. Es donde aprendí el oficio, pues el padre Alfonso Sahagún [director del semanario] no me daba clases, pero corregía mis artículos, mi español que para aquel entonces no era tan bueno, pero además me enseño los límites: un artículo de periódico no puede pasar de..., pues hay un problema de espacio y hubo que aprender a no hacer una larga disertación sino a condensar un tema y desde aquel entonces nunca lo dejé. A partir de 1990, escribí semanalmente en Uno más uno, hasta que un buen día Octavio Paz me dijo: «Jean, porque escribe en Uno más uno, está de capa caída, váyase a La fornada». Me fui a La fornada y duré muchos años hasta que el apoyo abierto de La fornada, no solamente a Fidel Castro, sino a ETA, hizo que, el mismo día, dos personas muy diferentes como Carlos Monsiváis y un servidor, mandáramos nuestra renuncia, y nos fuimos a El Universal, los dos, en la misma página de opiniones hasta la muerte de Carlos Monsiváis.

41 ID., La gran controversia. Las iglesias católica y ortodoxa de los orígenes a nuestros días, Tusquets, Barcelona, 2005.

42 Luis González y González (1925-2003): historiador mexicano director de la revista Historia mexicana, editada por El Colegio de México. Introductor del concepto de «microhistoria» y gran impulsor del mismo. Se cuenta entre los fundadores de El Colegio de Michoacán (1979), del que fue primer presidente de la Junta de Gobierno. Autor, entre muchos otros libros, de Pueblo en Vilo (1968), Invitación a la microhistoria (1971) y El oficio de historiar (1988). 
-Una columna, la suya, en la que se habla más del acontecer mundial que del mexicano...

-Prefiero escribir de temas internacionales porque la prensa mexicana es demasiado «ombliguista», el mundo exterior casi no existe. De vez en cuando escribo sobre México, pero hay muchos y buenos especialistas y cuando en la página de opiniones hay siete artículos sobre el Instituto Electoral, o sobre las elecciones, o sobre el narco... no voy a dar uno más. Nadie escribe sobre los cristianos de oriente amenazados de exterminio, poca gente escribe sobre el papa, el actual o Benedicto XVI, o sobre temas europeos, China, Tíbet...

P. Ya que cita a Benedicto XVI, en el 2010, yo recuerdo haber leído un artículo en el que usted afirma que pasaría a la bistoria como uno de los grandes reformadores...

R. Claro que sí...

P. En aquella ocasión, era curioso porque todos los columnistas, incluso gente bastante seria, atacaban al papa muy duramente. ¿Usted escribió ese artículo un poco para contraponerse a esa corriente de opinión?...

R. Me molestaba muchísimo esa idea del «doberman», del «panzerkardinal», que además se mezclaba con el «papa alemán», a ver: ¿cuál es el problema? Alemán-nazi, como una ecuación. Y siempre me pareció (yo lo he leído mucho) un filósofo, un pensador excepcional. Igual no le interesa a usted la prehistoria, hablaré de la revista Istor...

-Muchas gracias (en ese momento me obsequia un ejemplar del último número, dedicado a la prehistoria).

-La revista nace en el 2000 y siempre tiene un dossier, que en el número 2 se llamaba: El cristianismo, ifactor de concordia o de discordia? Yo había leído en Le Monde un resumen de una ponencia que el cardenal Ratzinger había dado en La Sorbona, en la que hacía una comparación entre el relativismo en Roma a vísperas del nacimiento de Cristo, y el relativismo actual en nuestra sociedad. De manera muy ingenua, escribí a Le Monde diciendo: «jpodrían conseguirme el texto?», y me dicen: «No, pues no lo ha dado el cardenal Ratzinger». Estaba de nuncio monseñor Bertello, habíamos simpatizado, y le di una carta para el cardenal, donde le pedía permiso de publicar [la ponencia] en la revista Istor. Me mandó el texto, lo publicamos, es un texto hermoso. Yo desde aquel momento leí lo que escribía este gran pensador. Reaccioné al escándalo increíble que hicieron por su discurso en Ratisbona, el «insulto» al islam sacando una cita de su contexto. Escribí un artículo para explicar cómo era y quién era el emperador, el basileús, que había escrito lo que citaba el papa, y en qué condiciones, y cómo ese papa era un hombre de diálogo, porque la obra citada por el papa era diálogo entre un cristiano y un filósofo persa... 
P. Para quienes leemos su columna, pudiera uno pensar que usted es un ecologista convencido. ¿Es asi?

R. Siempre he tenido la idea, que está en Génesis, de que el mundo, la tierra es el jardín, y que no somos dueños: somos el hortelano encargado de...; lo mismo que nos confió a los animales. San Francisco de Asís es el creador, el introductor de la ecología en sentido amplio, de que los animales, de que la naturaleza, de que la tierra misma es la creación de Dios y que tenemos el usufructo, pero no podemos ser como los malos inquilinos que destruyen todo antes de irse. Un cristiano informado obviamente debe llegar a este tipo de conclusiones, además, ahí está la famosa tesis del bien común que formularon los pensadores de la Edad Media, pero que es anterior, la podemos encontrar ya en san Agustín. El bien común pasa por eso...

P. Dos preguntas más, o más bien, una pregunta doble para ya no abusar más de su tiempo, y le agradezco infinitamente el que me ba dedicado. ¿Cuáles eran sus expectativas cuando llegó a México, y cómo ve ahora a México?

R. Cuando llegué a México había un contraste muy fuerte entre un régimen que, políticamente, no me era agradable para nada. Un régimen muy extraño. La primera vez que llegué a México, yo tenía veinte años, era el apogeo de la revolución cubana, en 1962. Uno llega a México y un turista que pasa como yo y viaja por todo el país, ve a la entrada y a la salida de cada pueblo todo pintado con slogans revolucionarios: parecía que uno estaba en un país comunista, de partido único, pues se veía solamente el PRI por todos lados, y sindicatos, y CTM ${ }^{43}$, y los trabajadores de... con López Mateos (era el tiempo de López Mateos), los campesinos de... con López Mateos, los obreros... y, al mismo tiempo, obviamente no era Cuba.

Cuando volví a México, tres años después, en el Colegio de México nadie, con excepción de uno, era miembro del PRI, y ninguno votaba con excepción de éste que... tenía mucho valor de decir: yo soy PRI y voto PRI (era una buenísima persona, además), pero los demás decían: «¿a qué voy a votar, si de todos modos gana el PRI?» Luis González nos contaba, a su manera, muy chistosa: «en mi pueblo, en San José de Gracia, pues yo estoy en la lista de mi pueblo, fui a votar en la tarde, y un tío mío era de los que estaban en la mesa y me dijo: 'Luisito, para qué vienes, ya votaste'». Pero ese México, al mismo tiempo, era de una seguridad absoluta. ¡Qué contraste con el México de hoy! Aunque

43 Confederación de Trabajadores de México. Representaba al sector obrero dentro del Partido Revolucionario Institucional (PRI), que gobernó a México entre los años 1929 y 2000. 
muchos digan que no, sí es una democracia política con alternancia; si el PAN perdió las elecciones es porque las perdió, no se puede invocar fraude, pero la inseguridad que hay en México hoy en día era inimaginable. En aquel tiempo, uno podía atravesar a pie toda la ciudad de México a las tres de la mañana; ir de Coyoacán al Zócalo ${ }^{44}$, o al revés, porque había perdido los últimos transportes y no tenía dinero para tomar el taxi, y llegué a Coyoacán cansadísimo, pero no me había pasado nada. Hoy en día no me atrevería a hacer la prueba. Eso sí, el campo era muy violento, pero a la gente que no era del pueblo, o del lugar..., que no participaba en sus pleitos entre pueblos o entre familias, no le pasaba nada. A uno se le podía ponchar una llanta en carretera, en plena noche y el primer coche que pasaba se paraba para ayudar. Y uno estaba con su esposa y los niños chiquitos, cuento lo que nos pasó entre Atotonilco y La Barca, una camioneta se para y nos lleva al pueblo, el coche se queda, dejo a mi esposa y a los niños en un hotelucho y el señor de la camioneta me consigue un mecánico, regresamos y el coche está entero: nadie ha desarmado el coche ni lo ha robado... Hoy en día, no quisiera saber. Ahora, para no exagerar en el pesimismo, con todo y lo violento que México es hoy en día, es menos violento que ese México de los años 60 que pinto como maravilloso, pues las ciudades estaban tranquilas, pero en el campo la matazón era enorme: campesinos que mataban campesinos, por problemas de tierra, de sangre, vendettas... La ciudad, sí, era tranquila, incluso Tepito, uno podía ir a Tepito [el barrio bravo de la capital] y no le pasaba nada. Ahora que hay estudios sobre la violencia en México, hoy en día que ha repuntado, y mucho, creo que estamos a veinte homicidios por cien mil, mientras que en 1960 estábamos a sesenta por cien mil al año, pero la prensa no hablaba de eso. La nota roja de esos años era crímenes pasionales. Y, sin embargo, había muchas matazones. Pasamos la Navidad de 1967 en casa de don Luis [González], en San José de Gracia, en Michoacán. Su padrino, tío y padrino, que había sido el alma de la cristiada en San José de Gracia, el padre Federico González, en la misa del día 25 , celebra, y en la homilía regaña a la gente, porque en esa noche hubo 5 muertos, borrachos y qué sé... Recuerdo que Luis me dijo: «no te preocupes, Jean, a nosotros no nos toca, y además... hace diez años eran 10 muertos». Entonces, hay esos contrastes. México está en un momento difícil, pero no debemos dejarnos llevar por los medios de comunicación masiva, que son exageradamente pesimistas.

44 Coyoacán es un barrio típico de la ciudad de México que se encuentra a unos once kilómetros del Zócalo, nombre que se le da a la plaza de armas. 
-Luego, señalando hacia un extremo de la mesita rectangular que había en la sala en que me recibió, dijo:

-Mire, la entrevista del papa... [refiriéndose a la entrevista que unos días antes el papa Francisco había concedido a la periodista Valentina Alazraki]. El papa ahí dice: «no es la primera vez que México tiene problemas graves». Incluso habla de la cristiada, ¿no sé si usted leyó la entrevista?

-Solo una nota o dos del periódico, pero...

-Tiene que leer la entrevista completa. Alude a la cristiada, y dice como mis cristeros: «es que el diablo está muy enojado con México por el favor que le hizo Dios por la Virgen de Guadalupe». Eso suena mucho a una explicación de los cristeros: es un favor porque non fecit taliter omni nationi, por eso nos tocó la persecución religiosa, porque el diablo está enojado con México. El papa tiene razón: México ha pasado muchas crisis, muchas muy graves y feas, y siempre ha remontado. Por un lado están esos monstruos, esos bandidos, pero aquí al lado hay una obra y usted ve a esos albañiles, realmente mal tratados... Aquí los departamentos van a costar un millón y medio de dólares: quiero saber cuánto ganan los albañiles. Ahí duermen en la noche, unos mal que bien tienen baño, pero no tienen regadera. Ponen sobre tres ladrillos el comal, y con leña de la obra todas las noches están calentando su comida. Muchos son jóvenes, alguno que otro de cincuenta años, todos flacos, salen cubiertos de cemento, de buen humor... Cuando mi hija pasa en frente de ellos con su bebé, le dejan el paso, se paran... Ese es el otro México, el México que yo conocí con mis cristeros, lo que los antropólogos llaman el México profundo. Lo otro es terrible y tiene un costo de sufrimientos y de... Mi hija es psicoanalista, psicoterapeuta, y de repente le tocan adolescentes cuyo padre o cuya madre han sido secuestrados, o asesinados, o cuyo padre ha sido ejecutado y resulta que era del crimen organizado, y la niña creció en esto y tiene pesadillas... El costo terrible, pero creo que México tiene recursos, en sus profundidades. Para nosotros sería muy fácil regresarnos a Francia: nunca lo hemos pensado. Nunca sacamos nuestro dinero, ni en los peores momentos de las devaluaciones... Incluso nos ha pasado una cosa chistosa: en el 82, estábamos construyendo en Zamora. Después de un semestre en Francia, llegamos a México en julio, agosto, del 82, con ahorros: los ahorros franceses, para seguir con la obra. Voy al Banco de Zamora, un banco provincial, y me conocía el director. Llego con mis francos y le digo: «a cambiar a pesos». El señor hizo lo imposible, pero, sin decirme nada, para que no los cambiara: «no, espérese, ¿por qué tiene tanta prisa?... Véngase la semana próxima a cambiar...» «No, no, no, ahora». Me los cambia y... al día siguiente fue la devaluación, la de López Portillo [dice al tiempo que se ríe]... 


\section{$-i$ La terrible?}

-La terrible... Bueno, pues entonces..., nos reímos. Nos reímos diciendo bueno..., no es negocio, pero, al mismo tiempo, con mucho orgullo nunca sacamos dinero del país. Al contrario, metimos dinero.

-Pues muchísimas gracias, Dr. Meyer...

-Bueno..., realmente he hablado mucho...

Luego de terminar oficialmente la entrevista, todavía permanecemos conversando unos minutos más sobre aspectos relacionados con el conflicto religioso de los años 20-30s. Al Dr. Meyer se le nota un poco cansado, y lo debe estar después de casi dos horas que hemos estado hablando; sin embargo, se ve también que el tema al que ha dedicado una buena parte de su vida le apasiona tanto que es capaz de sobreponerse siempre al cansancio. Nos despedimos, por fin, quedando de intercambiar cierto material de interés común. La noche ha comenzado a caer. Los árboles de la avenida hacen el paisaje todavía más oscuro. A una manzana de la casa de Meyer, está una de esas glorietas con las que en otra época se pretendió dar a esta, y a otras calles de México, un supuesto aire afrancesado. En fin... son temas para dialogar en alguna otra ocasión. En esta, por lo pronto, he conseguido, y con creces, conocer más acerca de la vida de este hombre que supo dar luz a lo que era «un blanco en el mapa histórico de México». 